CASE REPORT

\title{
Cardiovascular stress on an elite basketball referee during national competition
}

A S Leicht

Br J Sports Med 2004;38:e10 (http://www.bjsportmed.com/cgi/content/full/38/4/e10). doi: 10.1136/bjsm.2003.006908

This case report examined the cardiovascular stress imposed on an experienced elite basketball referee during national competition. The average heart rate was similar for all matches, approximated $73 \%$ of maximum heart rate, and was experienced for most $(>63 \%)$ of the match. Similar relative exercise intensity was demonstrated regardless of match play (men's $v$ women's) and officiating type (two $v$ three-referee). Further study is needed to document the physiological characteristics of elite basketball referees for greater performance.

M ost research studies examining physiological stresses during elite competition have concentrated on the competitors of the sport. Very few studies have examined the physiological stresses on referees, umpires, and officials, with even fewer studies examining basketball referees. ${ }^{1}$ Given the increased physiological and psychological demands of elite competition, further understanding of the physiological stresses placed on officials is necessary for increased performance (that is, reduced errors). This case study examined the cardiovascular stress experienced by an elite basketball referee during national competition matches.

\section{CASE REPORT}

The cardiovascular stress experienced by a male referee (age 32 years; height $178 \mathrm{~cm}$; body mass $79 \mathrm{~kg}$; body mass index $24.9 \mathrm{~kg} / \mathrm{m}^{2}$; maximum heart rate $\left.\left(\mathrm{HR}_{\max }\right) 181 \mathrm{bpm}\right)$ was examined during four national basketball matches during 1 month of the 2002-2003 season. All matches were played during the regular season and included three elite men's matches $(4 \times 12 \mathrm{~min}$ quarters $)$ with three-referee officiating and one elite women's match $(4 \times 10$ min quarters $)$ with tworeferee officiating. The women's match was examined as there have been anecdotal suggestions that the greater involvement of all team players during women's matches and the use of only two referees results in greater stress on referees. The referee was an experienced national and international official who had officiated at basketball matches for approximately 17 years, including 8 years in the national men's basketball competition and over 2 years in international basketball competitions. The referee had met all requirements for appointment to matches including referee ability and fitness levels deemed appropriate by the national governing body.

Cardiovascular stress was determined from heart rate (HR) recordings using a POLAR S610 HR monitor (sampling every 5 s) from immediately prior to the start of each match until immediately following the match, including all breaks (for example, half time, time outs, etc). The relative exercise intensity experienced by the referee was classified as: very hard $\left(>90 \% \mathrm{HR}_{\max }\right)$, hard $\left(70-89 \% \mathrm{HR}_{\max }\right)$, moderate $(55-$ $\left.69 \% \mathrm{HR}_{\max }\right)$, and light $\left(35-54 \% \mathrm{HR}_{\max }\right)$ according to American
College of Sports Medicine guidelines. ${ }^{2}$ The proportion of the total match time located within these categories was examined.

The average match HR (approximately $130 \mathrm{bpm}$ ) was similar for all matches and represented an average exercise intensity of approximately $73 \% \mathrm{HR}_{\max }$ (table 1 ). Most (>63\%) of the match time was spent at an exercise intensity greater than $70 \% \mathrm{HR}_{\max }$. Despite the women's match being shorter in total time and involving only two referees, the average HR and HR range were similar to those experienced by the referee during the men's matches (table 1).

\section{DISCUSSION}

The current results indicate that an elite basketball referee experiences significant cardiovascular stress during competition. Further, the basketball referee experienced similar physiological stress during the men's and women's matches and similar stress regardless of the officiating type (that is, two $v$ three referees). Reports of well officiated game performances from a referee observer and the referee himself indicated typical game responses rather than heightened stress due to HR monitoring. However, as the referee had excellent experience in both national and international competition, the HR responses demonstrated may in fact underestimate the stresses of national basketball referees. It remains to be seen whether the physiological responses of inexperienced officials differ from those demonstrated in the current case study.

Three-referee officiating in basketball in Australia was introduced in 1993 based upon the primary need for greater game coverage and increased referee performance, possibly by reducing the physiological stress on referees. ${ }^{3}$ The current results do not support this notion of a reduced exercise workload during elite competition but demonstrate that elite basketball referees perform exercise at a high intensity $\left(>70 \% \mathrm{HR}_{\max }\right)$ for approximately $2 \mathrm{~h}$, regardless of game play and officiating type. Greater cardiovascular stress (mean HR of $155 \mathrm{bpm}$ ) has previously been reported for basketball referees during high school matches. ${ }^{1}$ However, these referees were deconditioned and overweight resulting in greater physiological stresses. ${ }^{1}$ Advances in both referee professionalism and the athleticism of basketball players render it impossible for such deconditioned referees to officiate at the elite level today. ${ }^{3}$

The level of cardiovascular stress observed in the current case study has also been reported for elite Danish soccer assistant referees. ${ }^{4}$ These officials experienced a mean HR (137 bpm) and HR range (130-170 bpm) similar to those of the current basketball referee. ${ }^{4}$ Other studies have reported greater workloads and physiological stresses for soccer referees..$^{5-7}$ The size of the playing field and bioenergetics of the different sports makes direct comparisons difficult between referees. However, it would appear that elite officials

Abbreviations: $H R$, heart rate 
Table 1 Relative exercise intensity experienced during each basketball match

\begin{tabular}{|c|c|c|c|c|}
\hline & $\begin{array}{l}\text { Match 1, } \\
\text { men's }\end{array}$ & $\begin{array}{l}\text { Match 2, } \\
\text { women's }\end{array}$ & $\begin{array}{l}\text { Match 3, } \\
\text { men's }\end{array}$ & $\begin{array}{l}\text { Match 4, } \\
\text { men's }\end{array}$ \\
\hline Match time (min) & 119.4 & 107.8 & 116.4 & 119.8 \\
\hline Average HR (bpm) & $\begin{array}{l}131.1 \\
(15.1)\end{array}$ & $\begin{array}{l}130.8 \\
(19.6)\end{array}$ & $\begin{array}{l}130.9 \\
(16.0)\end{array}$ & $\begin{array}{l}136.3 \\
(16.6)\end{array}$ \\
\hline $\begin{array}{l}\text { HR range (bpm) } \\
\text { Proportion of match }\end{array}$ & $\begin{array}{l}93-166 \\
\text { time }(\%)\end{array}$ & $85-166$ & $92-162$ & $91-177$ \\
\hline $\begin{array}{l}\text { Very hard } \\
\left(>90 \% \mathrm{HR}_{\max }\right)\end{array}$ & 0.6 & 0.3 & 0.0 & 4.1 \\
\hline $\begin{array}{l}\text { Hard }(70- \\
\left.89 \% \mathrm{HR}_{\max }\right)\end{array}$ & 64.4 & 63.5 & 68.4 & 69.6 \\
\hline $\begin{array}{l}\text { Moderate }(55- \\
\left.69 \% \mathrm{HR}_{\max }\right)\end{array}$ & 30.9 & 25.4 & 26.6 & 25.7 \\
\hline $\begin{array}{l}\text { Light (35- } \\
\left.54 \% \mathrm{HR}_{\max }\right)\end{array}$ & 4.1 & 10.8 & 5.0 & 0.6 \\
\hline
\end{tabular}

\section{Take home message}

An elite basketball referee experiences high intensity exercise during national competition matches and similar cardiovascular stress irrespective of match play and officiating type.

in various sports experience similar high intensity exercise during elite competition, a situation which warrants further investigation.

There have been increasing efforts to document the minimum level of physical fitness required for basketball officiating, ${ }^{1}$ however these efforts have been driven largely by governing bodies without scientific basis. Further research is needed to identify the physiological characteristics necessary for elite basketball referees and the development of appropriate training regimes for elite officials.

\section{Information box}

A prior study examining high school basketball referees has demonstrated significant cardiovascular stress on referees during regional competition. However, no study to our knowledge has examined the cardiovascular demands of elite competition on basketball referees. The current study has demonstrated that an elite basketball referee experiences significant cardiovascular stress $1>70 \%$ maximum heart rate) for most of a national competition match regardless of match play and officiating type. Future studies are necessary to identify the physiological characteristics needed for elite basketball officials.

Conflict of interest: none declared.

Correspondence to: Anthony S Leicht, James Cook University, Institute of Sport and Exercise Science, Angus Smith Drive, Townsville, QLD 4811, Australia; Anthony.leich†@jcu.edu.au

Received 13 July 2003

Accepted for publication 15 July 2003

\section{REFERENCES}

1 Holland JC, Cherry RB. Aerobic capacity, body composition, and heart rate response curves of high school basketball officials. J Sports Med 1979;19:63-72.

2 Pollock ML, Gaesser GA, Butcher JD, et al. American College of Sports Medicine Position Stand. The recommended quantity and quality of exercise for developing and maintaining cardiorespiratory and muscular fitness, and flexibility in healthy adults. Med Sci Sports Exerc 1998;30(6):975-91.

3 Mildenhall B. Three person officiating: appropriate or inappropriate. Report submitted to One Basketball. Sydney, Australia, 2002.

4 Krustrup P, Mohr M, Bangsbo J. Activity profile and physiological demands of top-class soccer assistant refereeing in relation to training status. J Sports Sci 2002;20:861-71.

5 D'Ottavio S, Castagna C. Physiological load imposed on elite soccer referees during actual match play. J Sports Med Phys Fitness 2001;41(1):27-32.

6 Weston M, Brewer J. A study of the physiological demands of soccer refereeing. J Sports Sci 2002;20:59-60.

7 Catterall C, Reilly T, Atkinson G, et al. Analysis of the work rates and heart rates of association football referees. Br J Sports Med 1993;27(3):193-6. 